\title{
Multi-Criteria Decision Analysis for the Land Evaluation of Potential Agricultural Land Use Types in a Hilly Area of Central Vietnam
}

\author{
Ronja Herzberg ${ }^{1}$, Tung Gia Pham ${ }^{2,3, * \mathbb{D}}$, Martin Kappas ${ }^{2}{ }^{\mathbb{D}}$, Daniel Wyss ${ }^{2}$ and \\ Chau Thi Minh Tran ${ }^{3}$ \\ 1 Faculty of Geoscience and Geography, Göttingen University, 37077 Göttingen, Germany; \\ ronja.herzberg@stud.uni-goettingen.de \\ 2 Cartography, GIS and Remote Sensing Department, Göttingen University, 37077 Göttingen, Germany; \\ mkappas@gwdg.de (M.K.); daniel.wyss@uni-goettingen.de (D.W.) \\ 3 Faculty of Land Resources and Agricultural Environment, University of Agriculture and Forestry, \\ Hue University, Hue 0234, Vietnam; tranthiminhchau@huaf.edu.vn \\ * Correspondence: phamgiatung@huaf.edu.vn or giatung.pham@stud.uni-goettingen.de; Tel.: +84-905261801 \\ or $+49-15905337897$
}

Received: 20 May 2019; Accepted: 31 May 2019; Published: 3 June 2019

\begin{abstract}
Land evaluation is a process that is aimed at the sustainable development of agricultural production in rural areas, especially in developing countries. Therefore, land evaluation involves many aspects of natural conditions, economic, and social issues. This research was conducted in a hilly region of Central Vietnam to assess the land suitability of potential agricultural land use types that are based on scientific and local knowledge. In the frame of this research, Participatory Rural Appraisal (PRA); Analytical Hierarchy Analysis (AHP); Geographic Information System (GIS); and, scoring based scientific literature and local knowledge were applied for Multi-Criteria Decision Analysis (MCDA) for land use evaluation. The results of the PRA survey reveal that five plants offer great agricultural potential in the research area, namely rice, cassava, acacia, banana, and rubber. The land suitability of each plant type varies, depending on physical conditions as well as economic and social aspects. Acacia and cassava represent the most suitable plant types in the research area. Recommendations regarding agricultural land use planning in the A Luoi district are brought forward based on the land evaluation results. The combination of scientific and local knowledge in land assessment based on GIS technology, AHP, and PRA methods is a promising approach for land evaluation.
\end{abstract}

Keywords: Land evaluation; GIS; Analytical Hierarchy Analysis (AHP); Participatory Rural Appraisal (PRA); local knowledge

\section{Introduction}

Today's world population of 7.5 billion is projected to rise to 9.7 billion until 2050 [1]. Demographic developments, changing consumption patterns, and climate change are expected to reinforce the pressure on land and to increase the risk of food insecurity, especially in developing countries [2]. While the United Nations, with the second Sustainable Development Goal (SDG), strives to end all forms of hunger and malnutrition until 2030, to date, 793 million people still suffer from undernourishment [3]. The goal of the United Nations can only be achieved if growth agricultural production exceeds population growth through a sustainable intensification of existing, but limited, agricultural land [2]. Meanwhile, land resources are central to agricultural production and inseparably connected with food security [2]. Therefore, research regarding land resources should be carried out in a comprehensive way 
when considering the physical as well as socio-economic factors [4]. On the regional scale, the active participation of stakeholders can lead to a better and informed decision making process [5].

Vietnam is an agricultural country in Southeast Asia that is characterized by population pressure and land scarcity [6]. In 2016, 64\% of the Vietnamese population resided in rural regions and $42 \%$ of the total labor force worked in the agricultural sector [7]. Therefore, the effective management of land resources for agricultural production in Vietnam is an essential requirement for food security and sustainable rural development. Despite the area of agricultural land expanding from $22 \%$ in 2005 to $39 \%$ in 2016, the productivity and the value of agricultural production in Vietnam still remains lower in comparison to other countries of the region, such as Thailand and China [7]. The inappropriate use of agricultural land is a major constraint to agricultural production in Vietnam [8].

Land evaluation is a process for predicting the land's suitability for a specific land use type (LUT) in a given area. Land evaluation provides a rational basis for land use planning [9], especially in developing countries, where an increase of arable land, which is often limited by negative effects of land degradation and environmental issues [10]. Distinct methods and models have been applied for land evaluation, such as Linear Combination, Simple limitation, fuzzy-logic modelling, the use of Artificial Neural Networks, and the Analytical Hierarchy Process (AHP) [11-16]. Despite some limitations, the AHP is still the most commonly applied method for land evaluation, especially on a small scale [17-19].

Determining the requirements for a LUT and scoring the suitability level has significant impact on land evaluation results [20]. The Food and Agriculture Organization of the United Nations (FAO) (1996) [21] suggested that climate, soil, and landform are the necessary requirements for land evaluation from an ecological perspective. Sys et al. (1993) [22] provided the reference values for physical crop requirements for fifty crop types that are commonly cultivated in the tropical and sub-tropical regions. These values have been applied by many researchers for land suitability evaluation [23-27]. However, the crop requirements that were provided by Sys et al. (1993) [22] are not detailed enough for smaller areas with specific characteristics.. Therefore, most of the researchers modified the original crop requirements document to adapt to local conditions, experiences, and data availability [28,29]. Local knowledge in land evaluation is very significant for land use decision-making and land management in rural areas [30]. The integrated method of scientific and local knowledge in land evaluation can lead to improved sustainable agricultural production [31]. A combination of biophysical surveying, spatial modeling, and participatory methods are needed for effective land evaluation, according to the FAO (2007) [20].

Research on land evaluation requires a large amount of spatial data, which Geographical Information Systems (GIS) are capable of easily and efficiently handling. Therefore, many researchers have used GIS for land evaluation [32-34], a process, which enables the integration of multiple attributes and different criteria that are involved in decision-making. Land evaluation can be seen as a multi-criteria decision analysis (MCDA) process [35], which, when combined with GIS, can become a powerful approach for land evaluation $[34,36]$. GIS techniques play an indispensable role in spatial analysis, whereas MCDA provides a rich collection of tools for structuring decision problems, as well as evaluating and prioritizing alternative decisions [34].

This paper describes the integration of GIS and AHP methods that are based on scientific and local knowledge to determine the land suitability for some potential agricultural LUTs in a hilly district of Central Vietnam.

\section{Materials and Methods}

\subsection{Reseach Area}

The study area "A Luoi district" is located between $107^{\circ} \mathrm{E}$ to $107^{\circ} 30^{\prime} \mathrm{E}$ and $16^{\circ} \mathrm{N}$ to $16^{\circ} 30^{\prime} \mathrm{N}$ and it is situated around $60 \mathrm{~km}$ west of Hue city, in Central Vietnam (Figure 1). The climate at the research site shows tropical monsoon characteristics with an annual rainy season from September to 
December. The average yearly precipitation amounts to $3180 \mathrm{~mm}$, according to statistics from 2005 to 2015. The average temperature reaches its maximum in May and its minimum in January at $25{ }^{\circ} \mathrm{C}$ and $17^{\circ} \mathrm{C}$, respectively [37]. The research site exhibits a low mountainous topography, with elevations ranging from $60 \mathrm{~m}$ to $1760 \mathrm{~m}$ above sea level, and decreasing from west to east. The slope in the area is complex and steep, with an average of more than 20 degrees. According to the international soil classification system [38], there are four soil types within the research area, including acrisols (ferralic) (75\%), acrisols (arenic) (14\%), acrisols (humic) (6\%), and acrisols (hyperdystric) (5\%) [39].

A Luoi district has an area of 122,415 hectares (ha), of which 60,105 ha (49\%) are covered by protected forests, 57,492 ha (47\%) are agricultural land (including production forests), 2318 ha (2\%) represent water bodies, and 2500 ha $(2 \%)$ are residential and infrastructural areas [40].

Four ethnic minority groups are living in the research area, namely the Ta Oi, Co Tu, Van Kieu, and $\mathrm{Pa} \mathrm{Ko}$, accounting for 75\% of the total population. The majority Kinh people occupy 25\%. In 2015, the total population was 47,115 inhabitants with 12,405 households. The households living below the poverty line occupied $37 \%$ of the total households. The poverty line was defined as a monthly income per person less than 26 Euro [37].

Agricultural production and collection of forest products are the main livelihoods of the majority of local people. Agricultural labor accounts for $75 \%$ of the entire labor force [37]. Acacia, rice, rubber, cassava, and banana are the five main agricultural crops. In addition, there are a number of minor crops, such as corn, peanuts, and vegetables, which occupy a rather small area and do not have a significant impact on local people's livelihoods [37]. The lack of basic resources, such as financing options and modern agricultural knowledge, is one of the main obstacles to sustainable livelihood development, especially in agricultural cultivation [14].

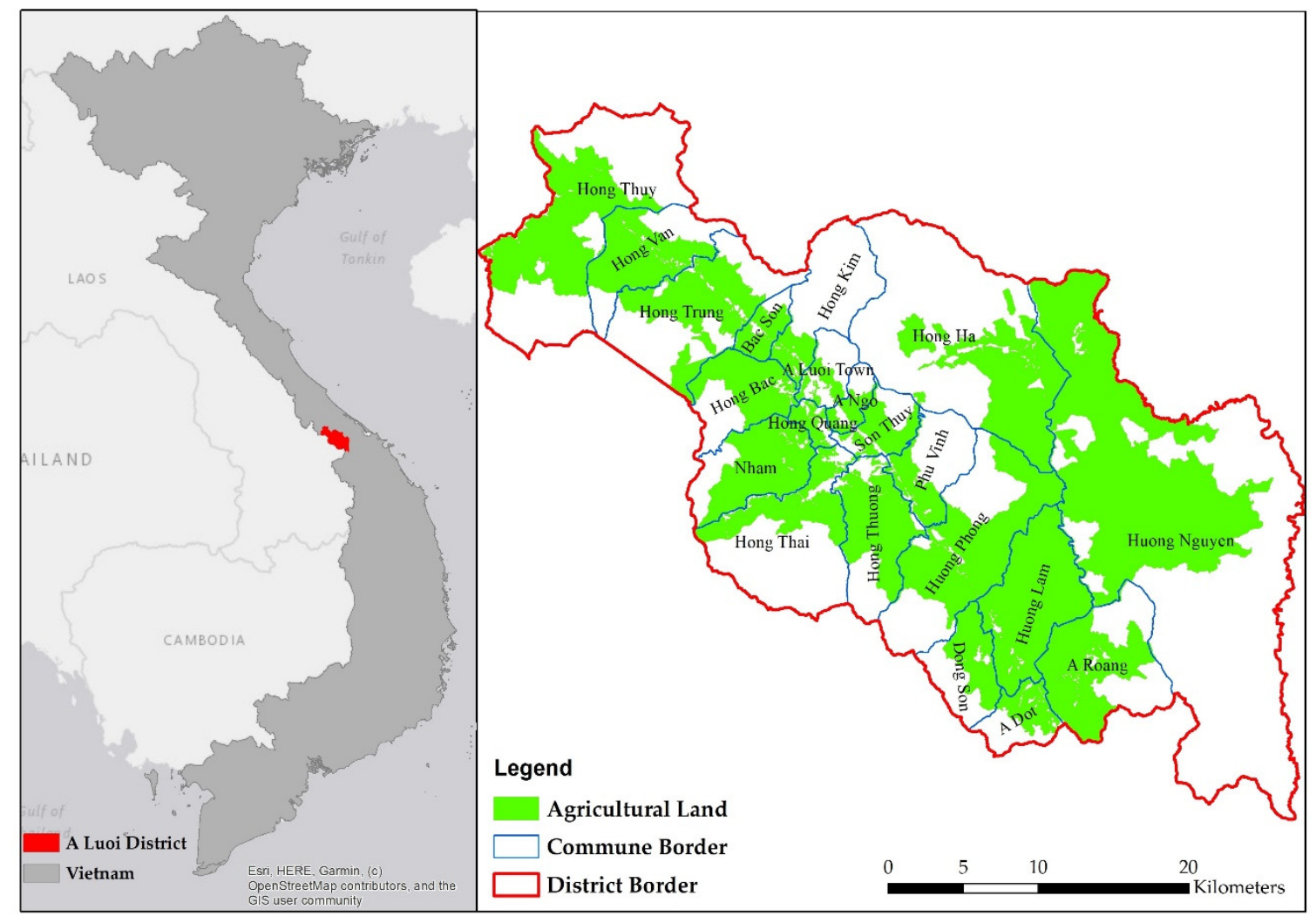

Figure 1. Research site and agricultural land use map.

\subsection{Material}

Input information plays an essential role for land evaluation. For each LUT, different values and ranges of criteria exist, defining the different suitability levels. For the selection of criteria, the available 
data, the cultivation history, and both local and worldwide knowledge need to be considered [41]. The available datasets for land evaluation included geospatial as well as descriptive information. In total, six teen land characteristics were chosen as the input layers for the land evaluation process listed in Table 1.

Table 1. List of data sets used in this study.

\begin{tabular}{|c|c|c|}
\hline Criteria & Data Source & Map Method \\
\hline $\begin{array}{l}\text { Physical Criteria } \\
\text { Soil type } \\
\text { Soil depth } \\
\text { Soil texture }\end{array}$ & $\begin{array}{l}\text { Soil map of Thua Thien Hue province } \\
(1: 100,000) \text { issued by NIAPP in } 2005 \text { [39]. }\end{array}$ & $\begin{array}{l}\text { Convert from Mapinfo } \\
\text { format (Tab) to ESRI } \\
\text { format (Shp) }\end{array}$ \\
\hline $\begin{array}{l}\text { Soil organic carbon } \\
\text { Soil total nitrogen } \\
\text { Soil } \mathrm{pH}\end{array}$ & Soil survey data of 155 soil sampling [42]. & $\begin{array}{l}\text { Ordinary kriging } \\
\text { (resolution at } 30 \mathrm{~m} \text { ) }\end{array}$ \\
\hline $\begin{array}{l}\text { Elevation } \\
\text { Slope }\end{array}$ & $\begin{array}{l}\text { Digital Elevation Model (DEM), resolution at } \\
30 \mathrm{~m} \text { [43]. }\end{array}$ & Original data \\
\hline Precipitation & $\begin{array}{l}\text { Average annual precipitation from } 2005 \text { to } 2017 \\
\text { based on three meteorological station in Thua } \\
\text { Thua Hue province [44]. }\end{array}$ & $\begin{array}{l}\text { Inverse Distance Weighting } \\
\text { (resolution at } 30 \mathrm{~m} \text { ) }\end{array}$ \\
\hline $\begin{array}{l}\text { Economic Criteria } \\
\text { Financial ability of family } \\
\text { Accessibility of farming } \\
\text { equipment } \\
\text { Labor income per day } \\
\text { Ability to sell product }\end{array}$ & $\begin{array}{l}\text { Group discussion/Participatory GIS and } \\
\text { Statistical data [37] }\end{array}$ & Community-wise \\
\hline $\begin{array}{l}\text { Social Criteria } \\
\text { Poverty rate } \\
\text { Labor force availability } \\
\text { Access to information } \\
\text { Farming skills }\end{array}$ & $\begin{array}{l}\text { Individual discussion/ Participatory GIS } \\
\text { Statistical data [37] }\end{array}$ & Community-wise \\
\hline
\end{tabular}

\subsection{Methods}

\subsubsection{Participatory Rural Appraisal (PRA)}

The PRA method enables the capturing of opinions from farmers and other key actors in agricultural and rural research [45]. In our study, the PRA method was used to select the potential crops as well as the assessment of physical and socio-economic aspects in respect to land suitability evaluation. The group discussion was implemented in eleven focus groups, with three to five people per group. The groups consisted of members of the Agricultural Department of the commune or district, the Natural Resources and Environment Department, the Labor and Social Affairs Department, and the Industry and Commerce Department of A Luoi district. Additionally, members of the district or commune committees, academics from Hue University, and farmers of the region participated in the discussions. Moreover, individual interviews were conducted with soil scientists and agronomy experts for the land evaluation regarding physical criteria (Table 2). 
Table 2. Participants in Participatory Rural Appraisal (PRA) method.

\begin{tabular}{|c|c|c|c|c|c|c|c|c|c|c|c|c|c|c|c|c|c|}
\hline \multirow{3}{*}{$\begin{array}{c}\text { Participants from } \\
\text { Outside Experts } \\
\text { Local Experts }\end{array}$} & & & & & & & \multicolumn{11}{|c|}{ Number of Participants } \\
\hline & & & & & & & & 9 & & & & & & & & & \\
\hline & & & & & & & & 21 & & & & & & & & & \\
\hline District's Agriculture and & & 1 & & & & & 苞 & & & 1 & & & & & & & \\
\hline $\begin{array}{l}\text { Hue University of } \\
\text { Agriculture and Forestry }\end{array}$ & & 1 & & & & & : & & 苞 & & & & & 2 & & $\overrightarrow{\tilde{g}}$ & 1 \\
\hline District's & $\tilde{0}$ & 1 & & & & & 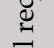 & & हु & 1 & & & & & & छ్ & \\
\hline $\begin{array}{c}\text { Hue University } \\
\text { of Economy }\end{array}$ & 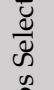 & & & & & & 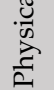 & & Z्. & & & & & 2 & & 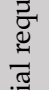 & \\
\hline $\begin{array}{l}\text { Natural Resources and } \\
\text { Environment Dept. }\end{array}$ & वें & & 1 & & & & 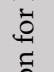 & & $\begin{array}{l}\text { हี } \\
0 \\
\tilde{0}\end{array}$ & 1 & & & & & & $\begin{array}{l}\text { Dू } \\
0 \\
1=\end{array}$ & \\
\hline $\begin{array}{l}\text { District's Labor and } \\
\text { Social Dept. }\end{array}$ & 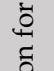 & & 1 & & & & $\begin{array}{l}0 \\
\text { 离 } \\
0 \\
0\end{array}$ & & $\begin{array}{l}0 \\
\text { पit } \\
\dot{0}\end{array}$ & & & & & & & 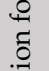 & 1 \\
\hline District's Commerce Dept. & 点 & & 1 & & & & .00 & & 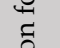 & 1 & & & & & & $\begin{array}{l}n \\
0 \\
2\end{array}$ & \\
\hline $\begin{array}{l}\text { Commune's } \\
\text { People Committee }\end{array}$ & $\begin{array}{l}\vec{J} \\
.0 \\
.0\end{array}$ & & & 1 & 1 & 1 & $\frac{\pi}{\frac{\pi}{3}}$ & & 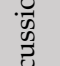 & 1 & 1 & 1 & 1 & & & $\underline{\mathscr{n}}$ & \\
\hline $\begin{array}{l}\text { Commune's } \\
\text { Agricultural Dept. }\end{array}$ & ईे & & & 1 & 1 & 1 & 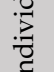 & & $\stackrel{0}{.0}$ & & 1 & 1 & 1 & & & $\stackrel{\pi}{\overparen{T}}_{0}^{\frac{\pi}{2}}$ & \\
\hline $\begin{array}{c}\text { Farmers } \\
\text { Agricultural Companies }\end{array}$ & जै & & & 3 & 3 & 3 & 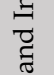 & & 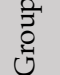 & & 3 & 3 & 3 & & 1 & $\underset{\overparen{Z}}{:}$ & \\
\hline Small Traders & & & & & & & $\Xi$ & & & & & & & & 2 & & \\
\hline $\begin{array}{l}\text { Center Rural Development } \\
\text { in Central Vietnam }\end{array}$ & & & & & & & ठี & & & & & & & & & & 1 \\
\hline Farmer's Union & & & & & & & & & & & & & & & & & 1 \\
\hline Total & 21 & 3 & 3 & 5 & 5 & 5 & 30 & 30 & 27 & 5 & 5 & 5 & 5 & 4 & 3 & 4 & 4 \\
\hline
\end{tabular}

\subsubsection{Criteria Weighting According to Analytical Hierarchy Process (AHP)}

The AHP theory that was developed by Thomas L. Saaty (1987) [46] is a MCDA approach. In scientific research on GIS-based land suitability evaluation, the approach is frequently applied for criteria weighting [15,47-50]. The AHP is a method for deriving a priority scale through pairwise comparison of attributes based on participant judgments [51]. The weighting of criteria through the AHP method was implemented, as follows:

(1) Selection of criteria and setting-up a hierarchy structure.

The hierarchical structure is composed of three levels with the overarching goal of determining the land suitability index for each LUT (Figure 2). The second and third levels show the criteria and sub-criteria influencing the decision. Each sub-criteria has different attributes describing specific characteristics, which have influence on the scoring algorithm for various LUTs. These characteristics need to have substantial influence on the productivity, feasibility, or sustainability of the agricultural land use [52]. In addition, critical values and a notable variation of criterion must be prevalent within the study area [53]. The final set of sub-criteria were selected and categorized with reference to the relevant literature [48,54-57], local expert knowledge, as well as local cropping guidelines that were provided by Nguyen et al. (2015) [52]. 


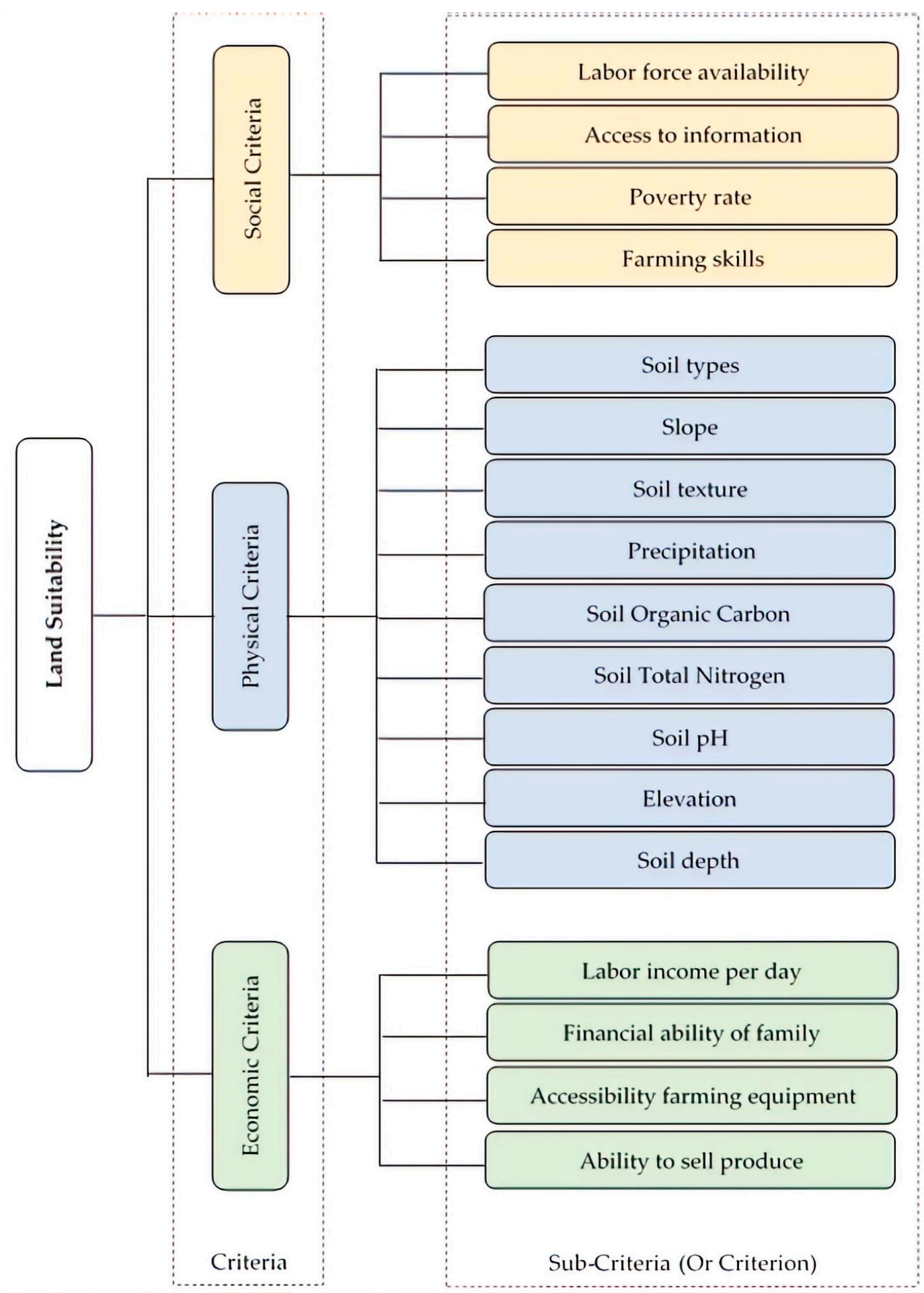

Figure 2. Hierarchical Structure of the Land Suitability Evaluation.

(2) Construction of pairwise comparison matrices according to the relative importance of each criterion (or sub-criterion).

The comparison matrices were derived from the experts' judgments and constructed, as described by Mu and Perevra-Rojas (2017) [58]. A numerical scale that was developed by Saaty (2008) [51] was used to compare these criteria (or sub-criteria), as shown in Table 3. 
Table 3. Verbal and numeric scale for the pairwise comparison of criterion according to the Analytical Hierarchy Process.

\begin{tabular}{cc}
\hline Numeric Scale & Response Alternatives of Experts \\
\hline 9 & Criterion $i$ is extremely more important than criterion $j$ \\
7 & Criterion $i$ is strongly more important than criterion $j$ \\
5 & Criterion $i$ is more important than criterion $j$ \\
3 & Criterion $i$ is slightly more important than criterion $j$ \\
$1 / 3$ & Criteria $i$ is equally important as criterion $j$ \\
$1 / 5$ & Criterion $i$ is slightly less important than criterion $j$ \\
$1 / 7$ & Criterion $i$ is less important than criterion $j$ \\
$1 / 9$ & Criterion $i$ is strongly less important than criterion $j$ \\
\hline
\end{tabular}

The geometric mean was applied to synthesize group judgments, as it represents the only mathematically correct way to aggregate reciprocal judgments $[59,60]$. The Original Matrix (A), which compares the priorities of all criteria against each other, was constructed.

$$
\begin{gathered}
A=\left(\begin{array}{ccccc}
1 & C_{12} & C_{1 i} & C_{1 j} & C_{1 n} \\
C_{21} & 1 & C_{2 i} & C_{2 j} & C_{2 n} \\
C_{i 1} & C_{i 2} & 1 & C_{i j} & C_{i n} \\
C_{j 1} & C_{j 2} & C_{j i} & 1 & C_{j n} \\
C_{n 1} & C_{n 2} & C_{n i} & C_{n j} & 1
\end{array}\right) \\
C_{i j}=\left(\prod_{k=1}^{m} a_{i j k}\right)^{\frac{1}{m}}
\end{gathered}
$$

where:

$C_{i j}$ is important level of criterion $i$ as compared to criterion $j$

$a_{i j k}$ is important level of criterion $i$ as compared to criterion $j$ according to expert $k^{\text {th }}$ $m$ is number of expert involves to discussion

Subsequently, the Normalized Matrix (B) is calculated from the A as Lee et al. (2012) [61].

$$
\begin{gathered}
B=\left(\begin{array}{lllll}
\bar{c}_{11} & \bar{c}_{12} & \bar{c}_{1 i} & \bar{c}_{1 j} & \bar{c}_{1 n} \\
\bar{c}_{21} & \bar{c}_{22} & \bar{c}_{2 i} & \bar{c}_{2 j} & \bar{c}_{2 n} \\
\bar{c}_{i 1} & \bar{c}_{i 2} & \bar{c}_{i i} & \bar{c}_{i j} & \bar{c}_{i n} \\
\bar{c}_{j 1} & \bar{c}_{j 2} & \bar{c}_{j i} & \bar{c}_{j j} & \bar{c}_{j n} \\
\bar{c}_{n 1} & \bar{c}_{n 2} & \bar{c}_{n i} & \bar{c}_{n j} & \bar{c}_{n n}
\end{array}\right) \\
\bar{C}_{i j}=\frac{C_{i j}}{\sum_{i=1}^{n} C_{i j}}
\end{gathered}
$$

where:

$\bar{C}_{i j}$ is normalized value of $C_{i j}$

$\sum_{i=1}^{n} C_{i j}$ is sum of $C_{i j}$ by column $j$ from matrix $\mathrm{A}$

$n$ is number of compared criteria

From the matrix B, the criteria weights can be derived, as follows:

$$
w_{i}=\frac{\sum_{j=1}^{n} \bar{C}_{i j}}{n}
$$




$$
W=\left(\begin{array}{c}
w_{1} \\
w_{2} \\
w_{i} \\
w_{j} \\
w_{n}
\end{array}\right)
$$

where:

$w_{i}$ is the weight of criterion $i$

$\sum_{j=1}^{n} \bar{C}_{i j}$ is sum of $C_{i j}$ by row $j$ from matrix B

(3) Validating the consistency of the final matrix of judgments.

A certain degree of inconsistency can be expected for criteria weightings based on group judgments. The consistency ratio enables the validation of the participant's answers by giving some indication on the compatibility and rationality between compared criteria. The consistency ratio was calculated, as suggested by Mu and Perevra-Rojas (2017) [58] and Saaty (1987) [46].

$$
C R=\frac{C I}{R I}
$$

where:

$C R$ is Consistency Ratio

RI is Random Index has already been provides by Saaty (1987) [46] as Table 4.

Table 4. Random Index based on number of criteria.

\begin{tabular}{ccccccccccc}
\hline $\mathbf{n}$ & $\mathbf{1}$ & $\mathbf{2}$ & $\mathbf{3}$ & $\mathbf{4}$ & $\mathbf{5}$ & $\mathbf{6}$ & $\mathbf{7}$ & $\mathbf{8}$ & $\mathbf{9}$ & $\mathbf{1 0}$ \\
\hline $\mathrm{RI}$ & 0 & 0 & 0.58 & 0.90 & 1.12 & 1.24 & 1.32 & 1.41 & 1.45 & 1.49 \\
\hline
\end{tabular}

$\mathrm{CI}$ is Consistency Index $(\mathrm{CI})$ is then obtained by calculating:

$$
\begin{aligned}
C I & =\frac{\lambda_{\text {max }}-n}{n-1} \\
\lambda_{\text {max }} & =\frac{\sum \frac{\sum_{j=1}^{n} w_{i *} C_{i j}}{w_{i}}}{n}
\end{aligned}
$$

According to Saaty (1987) [46], an inconsistency of $10 \%$ is acceptable. Hence, the weights of a judgment matrix characterized by a $C R \leq 0.1$ can be used for further analysis.

\subsubsection{Deriving Scores for Criteria Levels}

The level of each criterion ranges between the minimum and maximum values in the region, which results in a distinct LUT performance, depending on the respective LUT. Therefore, the scores need to be assigned indicating the suitability level of each attribute of each criterion for a given land use type [9].

Many authors [55] refer to the land evaluation guidebook by Sys et al. (1993) [22], which summarizes crop requirements for the tropics and sub-tropics. However, this guideline shows significant shortcomings, as it does not provide information regarding some essential criteria (soil total nitrogen, elevation, soil type), and additionally does not contain reference values for acacia requirements. Moreover, no information on economic or social criteria are given by Sys et al. (1993) [22], which are, for the growth of some crops, equally important as the physical characteristics of an area. Due to these reasons, we introduced an attribute scoring based on the opinions of local stakeholders 
that were gathered from the PRA survey, in addition to the common scoring approach that was derived from Sys et al. (1993) [22]. We combined the scores according to Sys et al. (1993) [22], where possible, with scores that were derived from the PRA survey and assigned a weight of $50 \%$ to each scoring approach in the final suitability map. In those cases, in which the literature does not provide any information, the PRA scores were fully applied for further analysis. A scale from three to nine was used to reflect the increment from a very unsuitable condition to very suitability conditions for a particular LUT (Table 5).

Table 5. Scale for scoring according to PRA method.

\begin{tabular}{cc}
\hline Score $\left(\boldsymbol{X}_{\boldsymbol{i}}\right)$ & Definition \\
\hline 9 & Criterion is suitable for evaluated LUT without any concerns. \\
7 & Criterion is suitable for evaluated LUT with few concerns. \\
5 & Criterion may be suitable for evaluated LUT with many concerns. \\
3 & Criterion is unsuitable for evaluated LUT. \\
\hline
\end{tabular}

\subsubsection{Suitability Classification}

The suitability can be measured with the suitability index $\left(\mathrm{S}_{\mathrm{i}}\right)$ (Table 6$)$, which represents a function of the weight and the score of each level of criterion regarding certain LUT. According to Huynh (2008) [14], the suitability index for one land mapping unit (LMU) and one LUT is described, as follows:

$$
\begin{aligned}
& S_{i}=\sum_{i=1}^{n} \bar{X}_{i} * w_{i} \\
& \bar{X}_{i}=\frac{\prod_{v=1}^{u} X_{i v}}{u}
\end{aligned}
$$

where:

$S_{i}=$ suitability index for a particular LMU and LUT

$\bar{X}_{i}=$ Score of $i^{t h}$ criterion

\begin{tabular}{|c|c|c|}
\hline PRA & Literature & Definition \\
\hline $8-9$ & $\mathrm{~S} 1(0)$ & Suitability of LMU is high and satisfies all considered criteria. \\
\hline $7-8$ & S1(1) & Suitability of LMU is high and satisfies most important considered criteria. \\
\hline $6-7$ & S2 & $\begin{array}{c}\text { Suitability of LMU is medium and satisfies most considered criteria, but some } \\
\text { criteria are not satisfied. }\end{array}$ \\
\hline $5-6$ & S3 & $\begin{array}{l}\text { Suitability of LMU is low and satisfies some considered criteria, but most } \\
\text { considered criteria are not satisfied. }\end{array}$ \\
\hline Less than 5 & $\mathrm{~N}$ & Not Suitable \\
\hline
\end{tabular}

Table 6. Scale for Suitability Index $\left(S_{i}\right)$ for Land Evaluation.

As a result of the PRA survey, a threshold of 5.0, which is equivalent to the level $\mathrm{N}$ according to Sys et al. (1993) [22], is used as a threshold for the areas that are unsuitable for the evaluated LUTs, which will be excluded from further analysis in our research.

\subsubsection{GIS Based Land Suitability Evaluation}

Seventeen thematic layers were created corresponding to the seventeen selected criteria for the land evaluation process. These maps were classified based on the PRA survey and literature. Afterwards, an intersection of all the layers was carried out to receive the land mapping units. The maps of land mapping units form the basis for analyzing the physical, economic, and social suitability of each land unit with respect to certain crop types. The calculation of suitability indices was performed 
using the attribute table of the vector layers, as suggested by Huynh (2008) [14]. The output of the suitability mapping will contain fifteen maps for all five crops showing their suitability with respect to the physical, economic, or social criteria. To receive the overall suitability, the three criteria-maps need to be overlaid for each crop. The weighted sum is used to create overall suitability maps for each crop. From the suitability maps of each kind of crop, the highest position tool was applied to analyze the most suitable land use for a particular land unit (Figure 3).

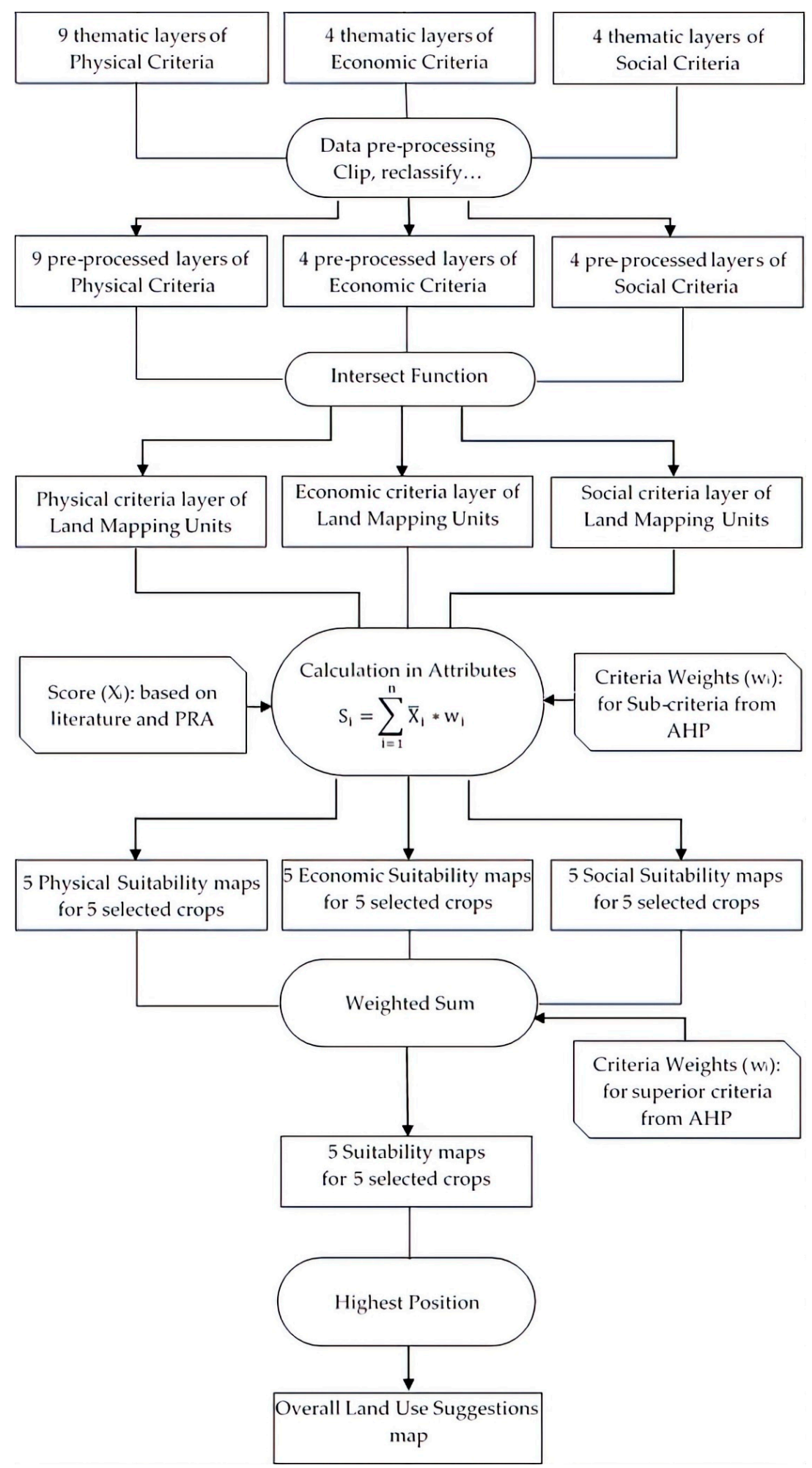

Figure 3. Flow chart of GIS-based land evaluation methodology. 


\section{Results}

\subsection{Selected Crops for Land Suitability Evaluation}

The group discussions led to the assumption that seven main crops are currently being cultivated in A Luoi district: acacia (Acacia spp.), cassava (Manihot esculenta), rice (Oryza sativa), rubber (Hevea brasiliensis), banana (Musa spp.), coffee (Coffea canephora), and different vegetables.

The pairwise comparison for the selection of land use type was conducted in-group discussions with 25 participants from different backgrounds. The result (Table 7) indicates that acacia, cassava, rice, rubber, and banana represent the most promising LUTs, and will hence be evaluated in this research.

Table 7. Final Ranking of Crops in A Luoi District for Land Suitability Evaluation derived from Pairwise Comparison of Experts.

\begin{tabular}{cccccc}
\hline & Physical Conditions & Economic Conditions & Social Conditions & Total & Final Rank \\
\hline Acacia & 0.136 & 0.172 & 0.045 & 0.353 & 1 \\
Cassava & 0.081 & 0.142 & 0.029 & 0.252 & 2 \\
Rice & 0.048 & 0.096 & 0.025 & 0.168 & 3 \\
Rubber & 0.032 & 0.043 & 0.008 & 0.084 & 4 \\
Banana & 0.027 & 0.036 & 0.007 & 0.070 & 5 \\
Vegetables & 0.016 & 0.021 & 0.006 & 0.044 & 6 \\
Coffee & 0.012 & 0.014 & 0.003 & 0.030 & 7 \\
\hline
\end{tabular}

\subsection{Characteristics of Physical, Economic and social LMUs}

The LMUs map contained 987 land units for different physical, economic, and social criteria.

\subsubsection{Layers of Physical Characteristics}

There are nine physical characteristics layers present in Figure 4.

* Slope: 13,500 hectares of the total study area, mainly located in the center of the valley, show moderate slope levels between 0 and 7.9 degrees. The slope level rises with increasing distance from the valley and the highest slope levels of more than 25 degrees are found along the mountainsides in the western part of the district.

* Elevation: The center of the valley and the eastern part of the district exhibit a low elevation level, with approximately 2000 hectares underneath the elevation thresholds of $500 \mathrm{~m}$. Nearly 30,000 hectares of the studied area show elevation levels between 501 and $750 \mathrm{~m}$. The remaining parts, especially in the west, mostly exceed an elevation of $1000 \mathrm{~m}$ above sea level.

* Soil type: The acrisol only represents the prevalent reference soil group within the research area. Acrisols (ferralic) cover the largest parts with 43,500 hectares and are scattered all over the district. Acrisols (arenic) occupy the second largest area with a size of 8700 hectares in the central east of the district. Acrisols (hyperdystric) can be exclusively found in the valley intersecting the district and Acrisols (humic) exclusively occur in small patches, mainly in the north-west of the district.

* Soil texture: Pure loam occupies the largest extent with an overall area of around 40,400 hectares. Clay loam is present on only 3500 hectares in the north and silt loam occupies 13,600 hectares in the valley and in the eastern parts of the district.

* Soil depth: A soil depth of more than $100 \mathrm{~cm}$ is prevalent on nearly 30,000 hectares, followed by a soil depth of 70-100 cm occupying about 15,000 hectares. Soil depths of less than $70 \mathrm{~cm}$ can be found on only $25 \%$ of the evaluated area.

* Soil pH: The soil in the entire area can be referred to as acidic. The soil pH ranges from 3.9 to 4.4. The soil $\mathrm{pH}$ of the central district is higher than in the remaining regions. 


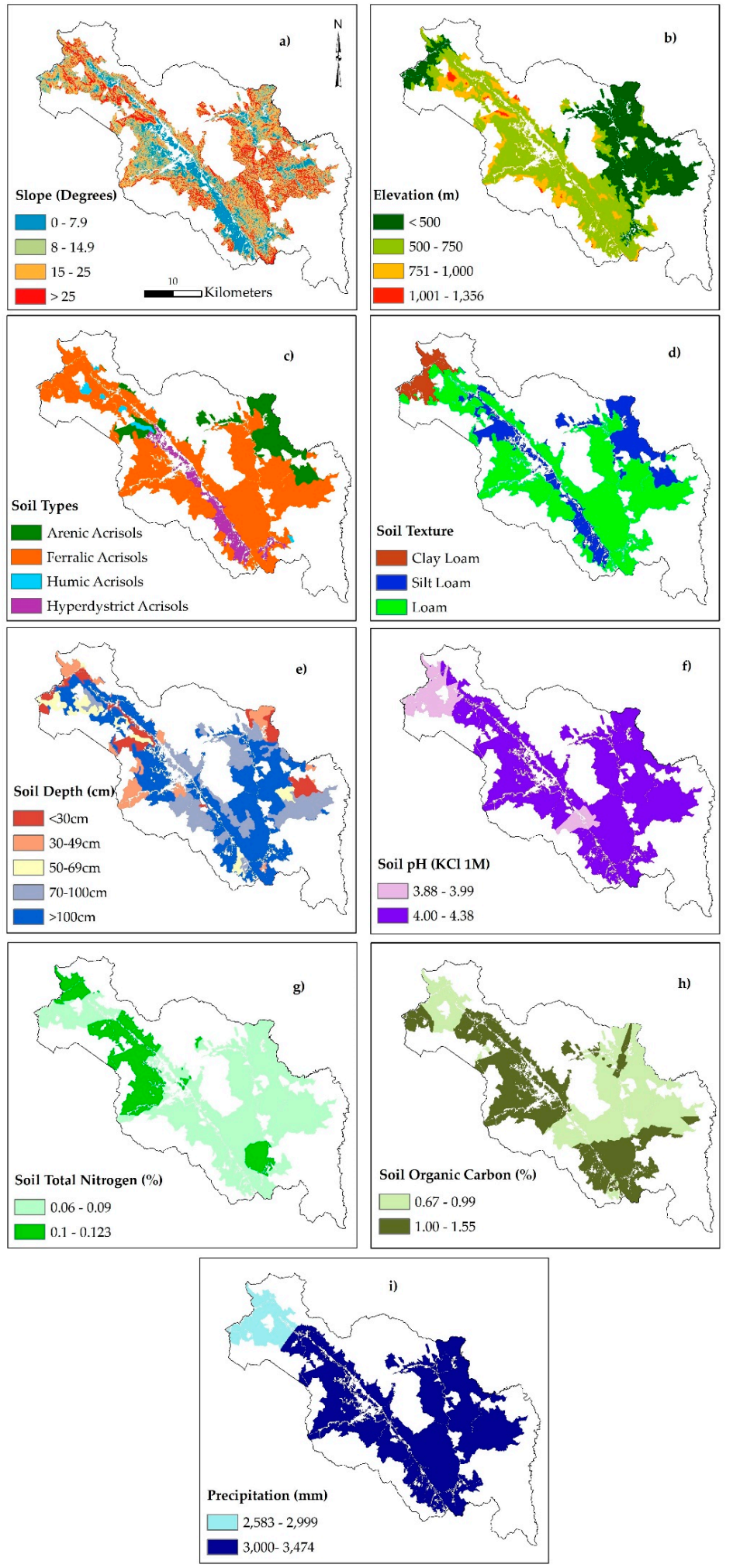

Figure 4. Geographic distribution of physical criteria in A Luoi district: (a) slope; (b) elevation; (c) soil types; (d) soil texture; (e) soil depth;(f) pH value; (g) soil total nitrogen; (h) soil organic carbon; and, (i) annual precipitation.

* Soil total nitrogen: The soil total nitrogen contents in the region vary between 0.06 and 0.12 percent of the soil weight. The lowest soil nitrogen levels can be found in the eastern region of the district, while higher ones can be measured in the central west, in the valley, as well as in the southern part. 
* Soil organic carbon: The average soil organic carbon contents in the region range between 0.67 and $1.55 \%$ of the soil weight. Similar to soil total nitrogen contents, soil organic carbon shows the highest levels in the valley and in the southern part of the district, while the soil organic carbon contents in the eastern part remain low.

* Precipitation: Due to the high mountains in the west, the precipitation in A Luoi district is rather high, varying between $2500 \mathrm{~mm}$ and $3500 \mathrm{~mm}$. Rainfall levels reach their maximum in the center of the district.

\subsubsection{Layers of Economic Characteristics}

There are four economic characteristic of economic layers as show in Figure 5.

* Financial ability of the family: This criterion refers to the financial ability of the family to invest in agricultural cultivation. The households in the center of the district are able to cover larger amounts of financial requirements for cropping by their own means.
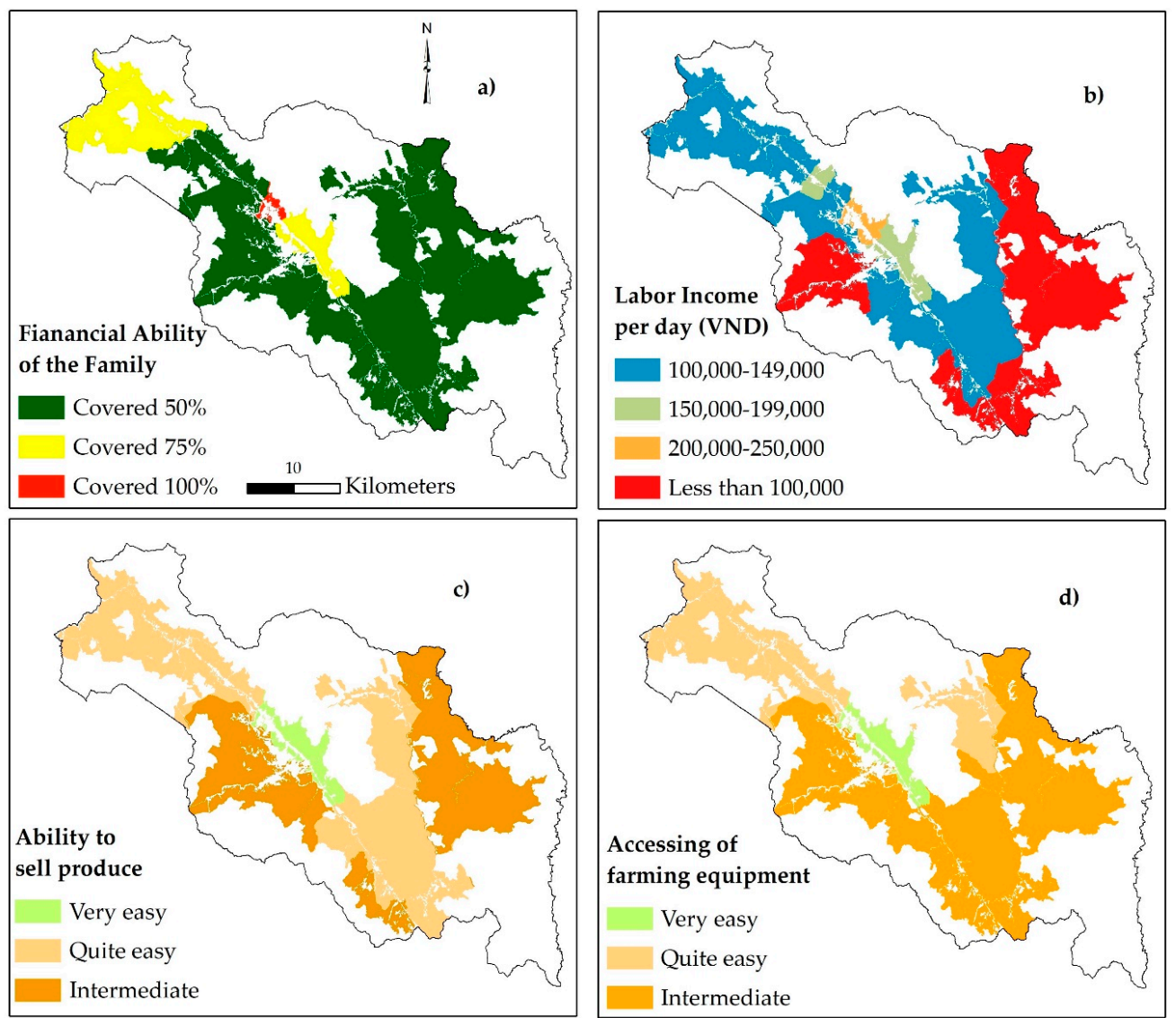

Figure 5. Geographic distribution of economic criteria in A Luoi district: (a) financial ability of the family; (b) labor income per day; (c) ability to sell produce; and, (d) accessibility of farming equipment.

* Labor income per day: The criterion describes the daily average income of a farmer who spends one day of work on the respective crop. The labor income per day plays an essential role in commercial LUTs, such as rubber, acacia, and banana. The income of people, who live in the communes that are located in the center of the district and in the lower terrain area, is higher than the labor income of other communes, as these offer other income opportunities. On average, their income amounts to more than 150,000 VND per day. While the labor income in the north was estimated between 100,000 and $149,000 \mathrm{VND}$ per day on average, in the mountainous communes along the southern and eastern district border, labor income falls below the line of 100,000 VND. 
* Ability to sell produce: The communes along the main road (national road) can quite easily sell their products. For the mountainous communes, located far away from the main roads, as well as the large rural commune of Huong Nguyen, the selling of produce is more challenging.

* Accessibility of farming equipment: This criterion describes the ability of a farm family to purchase farming equipment. Again, the communes located in favorable areas have better access to the inputs and agricultural machinery than other communes do.

\subsubsection{Layers of Social Characteristics}

There are four social characteristics layers present in Figure 6.

* Farming skills: One of the most challenging issues of farmers in the A Luoi district is the level of farming skills. Farming skills are vital, especially for agricultural LUTs, like rubber and banana. In general, most local farmers practice agriculture based on their experiences.
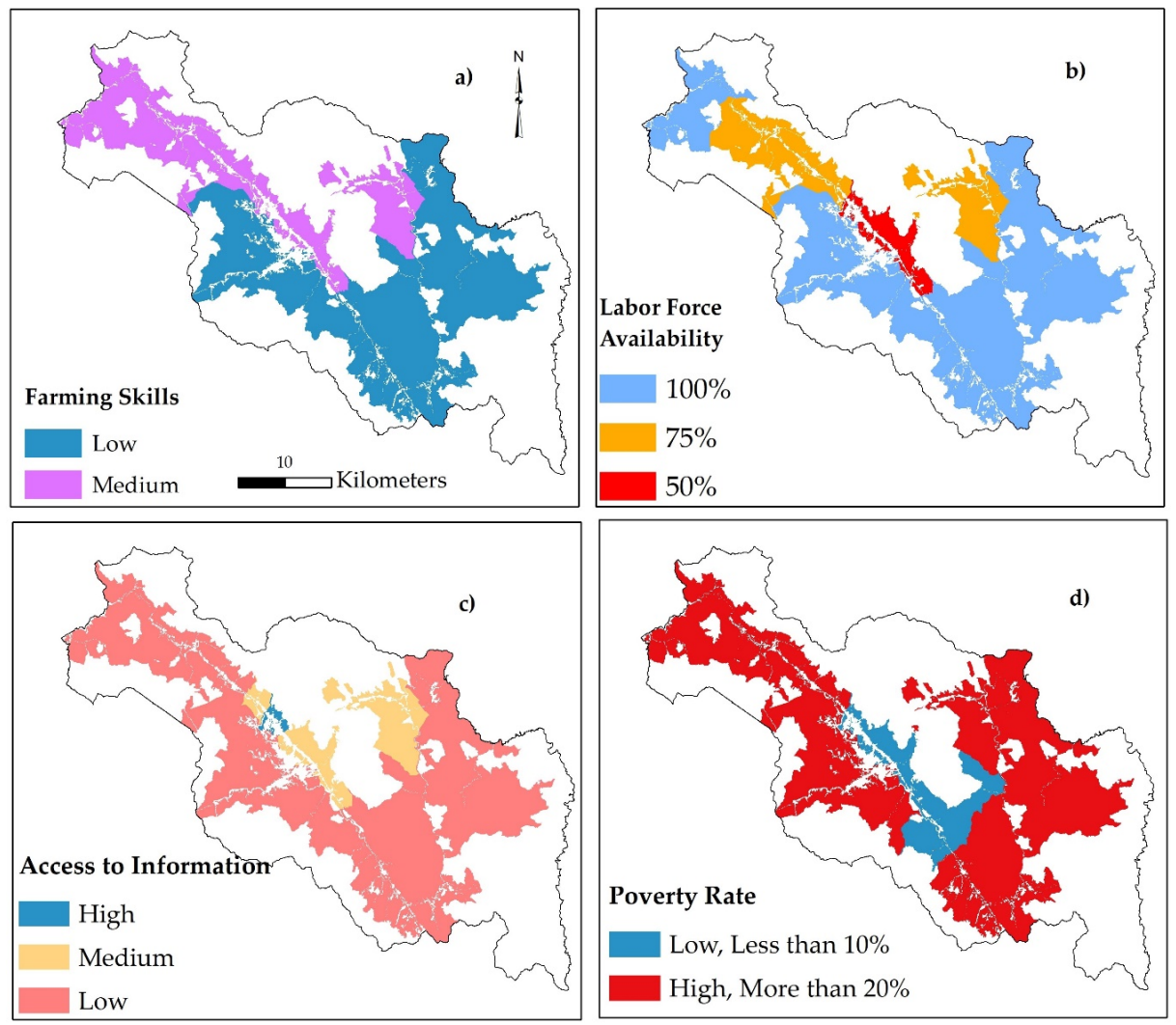

Figure 6. Geographic distribution of social criteria in A Luoi district: (a) level of faming skills; (b) labor force availability; (c) access to information; and, (d) poverty rate.

* Labor force availability: This criterion refers to the potential agricultural labor force that each household in the commune can provide. The local people in the central area have other income opportunities apart from agriculture, as already described in the context of labor income per day. As a result, the labor force that is available for agricultural production is lower than in rural and mountainous communes.

* Access to information: The information regarding agricultural practices and technologies is crucial for agricultural production, especially for commercial LUTs. According to the experts, only the inhabitants of A Luoi Town, which is characterized by favorable infrastructural conditions, are, on average, highly informed regarding new developments in the sector. Other communes in the valley and around A Luoi Town, as well as Hong Ha commune, are assigned a medium level of information, while the mountainous communes show a low level of information accessibility. 
* Poverty rate: The criterion estimates the share of commune's inhabitants living below the poverty line, which is defined at 700,000 VND per month. Around $37 \%$ of all households in the A Luoi district live below the poverty line. A low poverty rate is assigned to the least rural communes, as $\mathrm{A}$ Luoi Town and the adjacent communes in the valley. A high population living below the defined poverty line characterizes the remaining regions.

\subsection{Criteria Weights and Scores}

The criteria weighting shows the differences in the importance level of each criterion (or sub-criterion) on the different LUTs (Table 8). In general, the economic aspects play an essential role in commercial LUTs, such as rubber, acacia, and banana. Hence, on the highest level of the hierarchy, the overall economic criterion was assigned a considerably higher priority for the commercial crops (all $>0.5)$ than for rice and cassava. As opposed to this, physical and social criteria seem to be more critical for rice and cassava LUTs than the economic criteria. Moreover, each sub-criterion has a different impact on the particular LUT. For example, with respect to physical conditions, soil quality criteria generally have a stronger influence than terrain criteria. Regarding economic criteria, the commercial agricultural LUTs (acacia, rubber, and banana) are mostly influenced by criteria that are associated with the market.

Table 8. Weights of overall Criteria (bold number) and Sub-Criteria based on Analytical Hierarchy Process (AHP).

\begin{tabular}{|c|c|c|c|c|c|c|c|c|c|c|c|}
\hline \multicolumn{2}{|r|}{ (Sub-)Criterion/LUTs } & \multicolumn{2}{|c|}{ Rice } & \multicolumn{2}{|c|}{ Cassava } & \multicolumn{2}{|c|}{ Acacia } & \multicolumn{2}{|c|}{ Rubber } & \multicolumn{2}{|c|}{ Banana } \\
\hline \multirow{9}{*}{$\frac{\vec{d}}{\stackrel{\Xi}{n}}$} & Soil type & & 0.18 & & 0.13 & & 0.17 & & 0.13 & & 0.14 \\
\hline & Slope & & 0.06 & & 0.06 & & 0.11 & & 0.07 & & 0.05 \\
\hline & Soil Texture & & 0.15 & & 0.07 & & 0.08 & & 0.08 & & 0.10 \\
\hline & Precipitation & & 0.14 & & 0.06 & & 0.05 & & 0.05 & & 0.04 \\
\hline & Soil Organic Carbon & 0.36 & 0.17 & 0.32 & 0.24 & 0.28 & 0.17 & 0.25 & 0.26 & 0.27 & 0.27 \\
\hline & Soil Total Nitrogen & & 0.13 & & 0.22 & & 0.17 & & 0.19 & & 0.22 \\
\hline & Soil pH & & 0.09 & & 0.07 & & 0.08 & & 0.05 & & 0.05 \\
\hline & Elevation & & 0.04 & & 0.05 & & 0.06 & & 0.05 & & 0.05 \\
\hline & Soil Depth & & 0.04 & & 0.09 & & 0.12 & & 0.13 & & 0.09 \\
\hline \multirow{4}{*}{ 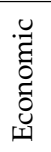 } & Labor income per day & & 0.18 & & 0.33 & & 0.24 & & 0.18 & & 0.13 \\
\hline & Financial ability of the family & 018 & 0.25 & 038 & 0.32 & 055 & 0.17 & & 0.20 & 0,50 & 0.15 \\
\hline & Accessibility of farming equipment & 0.18 & 0.41 & 0.38 & 0.21 & 0.55 & 0.08 & 0.58 & 0.10 & 0.59 & 0.09 \\
\hline & Ability to sell produce & & 0.16 & & 0.13 & & 0.51 & & 0.51 & & 0.62 \\
\hline \multirow{4}{*}{$\begin{array}{l}\text {.] } \\
\text { ర్ల } \\
\infty\end{array}$} & Labor Force Availability & & 0.45 & & 0.33 & & 0.32 & & 0.18 & & 0.28 \\
\hline & Access to Information & 047 & 0.20 & 030 & 0.17 & 017 & 0.23 & 0.8 & 0.19 & 11 & 0.15 \\
\hline & Poverty rate & 0.47 & 0.23 & 0.30 & 0.38 & 0.17 & 0.36 & 0.18 & 0.41 & 0.14 & 0.30 \\
\hline & Farming skills & & 0.11 & & 0.11 & & 0.08 & & 0.22 & & 0.27 \\
\hline
\end{tabular}

The scoring of the attribute of criteria (Table 9) is the assessment of the LUTs suitability with the particular attribute of each sub-criteria related to physical, economic, and social conditions. Regarding the criteria scoring, the attributes of all criteria were rated for each LUT with respect to the specific LUT requirements. For physical criteria, the scoring was carried out based on the PRA surveys as well as on literature that Sys et al. (1993) [22] provided. The result shows that the PRA scoring and literature scoring approach show similarities, but differ in their magnitude. Concerning physical criteria, low $\mathrm{pH}$ values, high levels of slope, as well as low soil fertility in the region are a limiting factor for all kinds of agricultural land use. On the contrary, the main soil texture attributes and precipitation levels are favorable regarding the majority of LUTs. With respect to economic criteria, low levels of economic criteria are assigned for most commercial LUTs. Regarding the prevailing social conditions within the study area, the differences between the commercial LUTs, except acacia, to the non-commercial LUTs can be observed. A low level of farming skills and information access, as well as a high poverty rate, in a more negative score for commercial crops. In general, the remaining LUTs are more resilient to unfavorable social circumstances. 
Table 9. Scores based on PRA and Literature scoring approach.

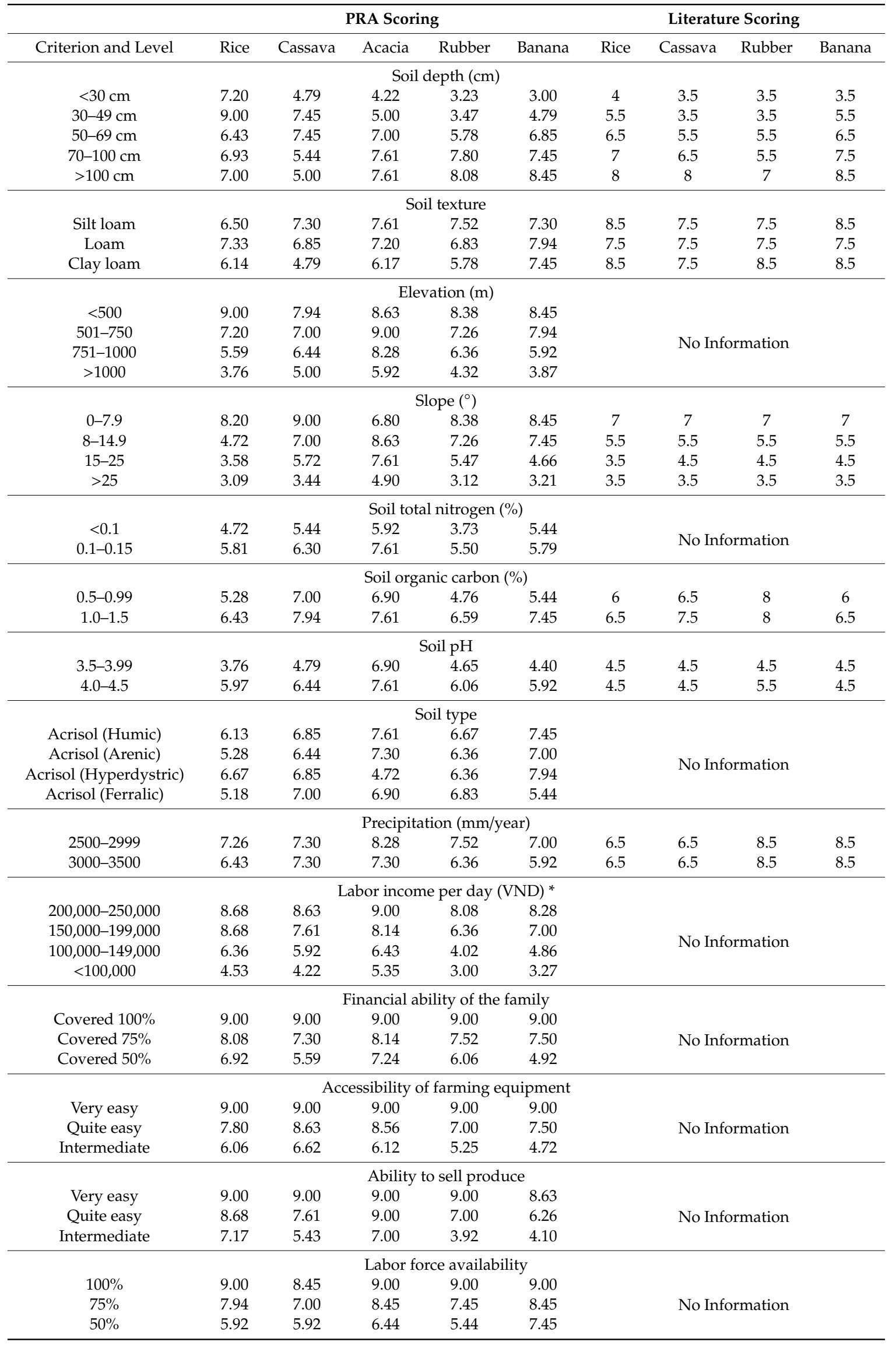


Son, Hong Trung, Hong Van, and Hong Thuy on of 1,388 hectares. The western, southern, and eastern parts are most the suitable for cassava cultivation with a large area of 23,835 hectares. The suitable areas for acacia account for 18,438 hectares, and they expand from the northern communes along the valley towards the southern and eastern parts of A Luoi district. The area for rubber cultivation type is small, with only five hectares in A Luoi Town. Small land units, summing up to the extent of 437 hectares in A Luoi Town and along the main road are suitable for banana LUT. Figure 7 presents the suitability map for each kind of LUT and Figure 8 presents the overall land use map for entire district.
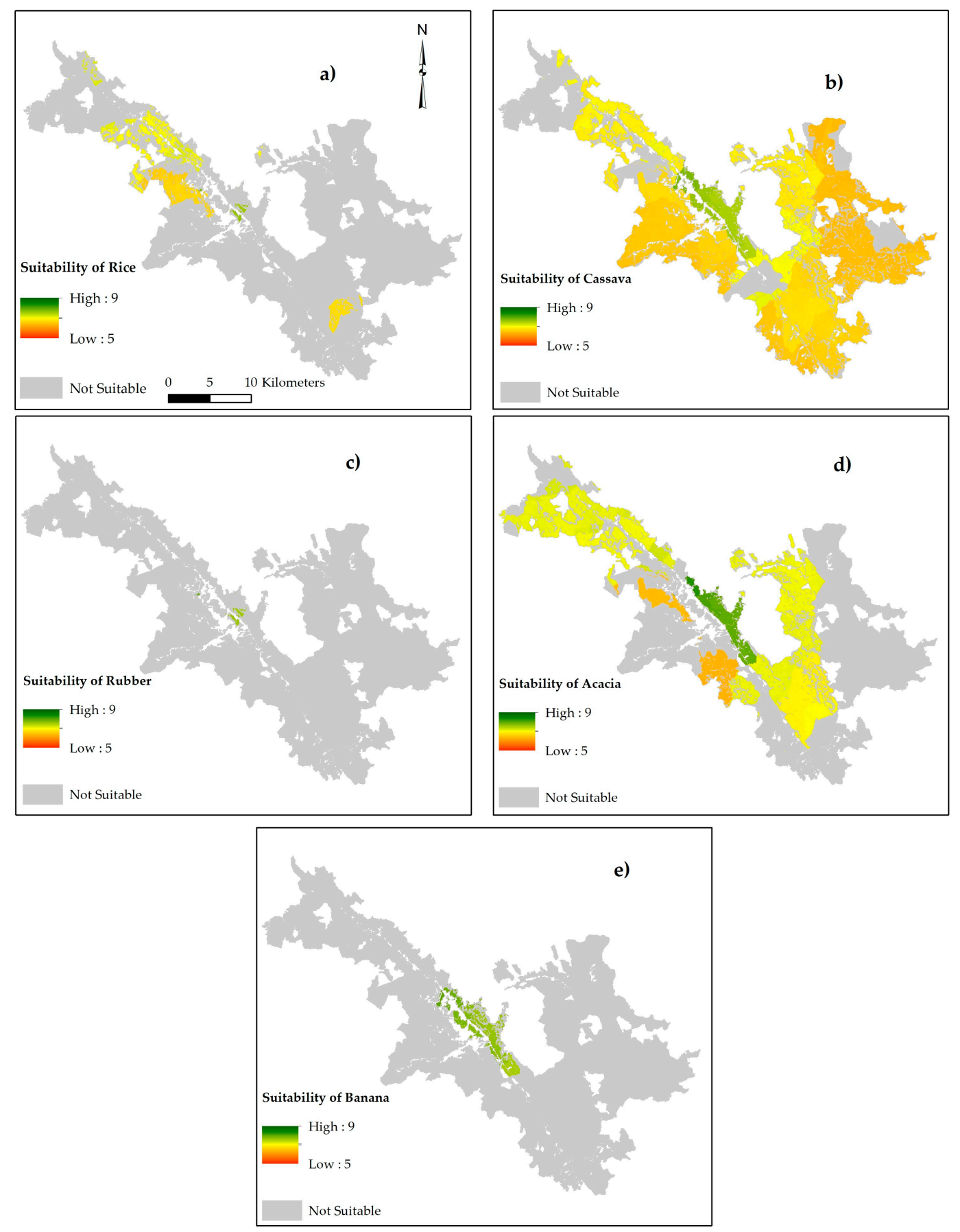

Figure 7. Land suitability for selected land use types: (a) suitability of rice; (b) suitability of cassava; (c) suitability of rubber; (d) suitability of acacia, and, (e) suitability of banana. 


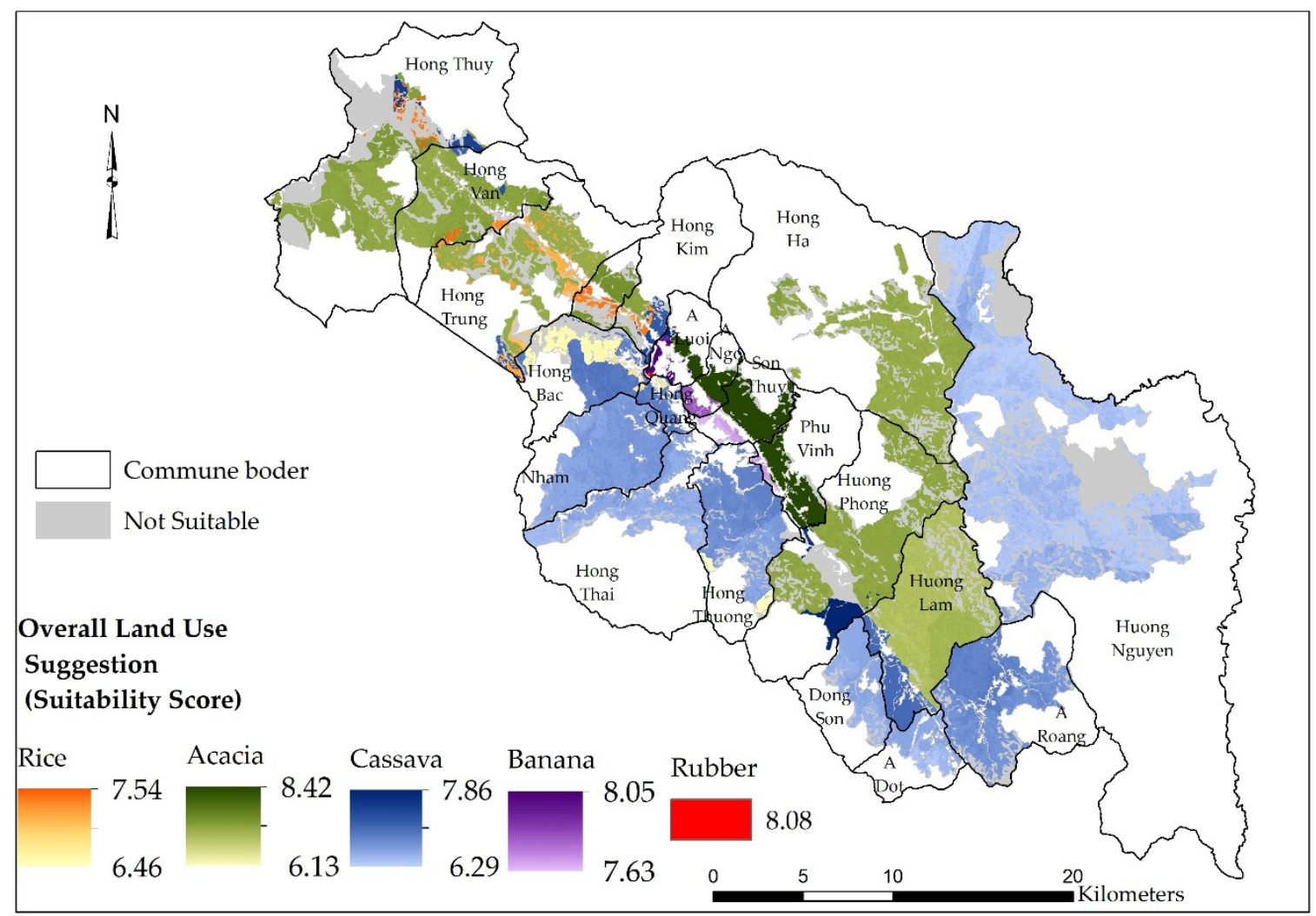

Figure 8. Overall land suitability of selected land use types for entire district.

\section{Discussion}

\subsection{Land Suitability Evaluation Methodology}

The implemented methodology of land suitability evaluation proved to be an appropriate and useful approach for the application in a hilly district of Vietnam. In the Vietnamese uplands, social and economic characteristics have a significant impact on agricultural land use [62]. The MCDA procedure allowed for the integration of physical, economic, and social criteria, as well as the involvement of local experts' judgments. However, these judgments can be highly variable in space and time, which thus leads to a trade-off between local knowledge involvement and objectivity. Moreover, it has limitations of independence among criteria [63]. Zolekar \& Bhagat (2015) [57] make use of correlation analysis to demarcate the most determining criteria for agricultural land use and to eliminate the interdependent ones, which would have been an adequate option to improve the data base.

The use of a Geographic Information System proved to be highly useful in the context of land suitability evaluation, as it facilitates the geographic assignment of criteria to land units. For physical criteria, random sampling and interpolation proved to be an adequate approach to represent the physical conditions in the area [42]. However, the Boolean approach still has limitations on the ability to express the transitional or continuous variation in geographical features [64]. To reduce this limitation, Fuzzy set theory [65] with partial membership function could be used as an appropriate solution [66,67]. With regard to the economic and social criteria, it must be noted that the community-wise assignment of characteristics leads to oversimplification, as socio-economic traits can differ considerably, even within communities. For a small-scale and more appropriate observation, a household survey on socio-economic factors regarding agricultural land use practices would be required. However, as stated by Yen et al. (2013) [62], a more complex approach to land suitability evaluation requires high quality data and sufficient resources to acquire such data.

This study indicates that the exclusive procurement of scoring values from Sys et al. (1993) [22] cannot draw a holistic picture of the local conditions. The land suitability evaluation that is based 
on the PRA survey differed considerably from this approach, particularly in the evaluation of the commercial crops rubber and banana. According to the guideline of Sys et al. (1993) [22], most agricultural land of A Luoi district would be unsuitable for crop production, due to soil being very acidic and the steep terrain. However, very diverse agricultural land use is taking place in the research area. This finding leads to the conclusion that site-specific knowledge regarding local characteristics cannot be captured by universally applicable literature. Therefore, this study suggests the integration of scientifically grounded literature on crop requirements and local knowledge in the form of a scoring through PRA methods.

\subsection{Limiting Factors for Agricultural Production}

Many environmental, economic, and social conditions of A Luoi district are unfavorable for agricultural production. Physical criteria, such as steep terrain, soil acidity, and low soil nitrogen are the main restrictions for agricultural cultivation, especially for commercial crops, like rubber and banana. Serious erosion rates, population pressure, and fallow cultivation have an additional negative effect on sustainable cultivation $[68,69]$.

Unfavorable economic conditions are mainly prevalent in the remote areas of the study area due to infrastructural and physical limitations [70], which particularly affect the production of commercial crops. An essential requirement for this kind of land use is the long-term financial ability. This requires significant investments during the early period of crop production, with expected benefits at a later stage [71]. In the last years of the life span, the productivity and quality of agricultural products will significantly reduce, leading to economic risks for the local people [72]. Hence, from an economic viewpoint, the accessible and central municipalities are the most suitable for agricultural land use.

The evaluated crops are most suitable in the lowland where lowest poverty rates, sufficient access to information, and a higher level of farming skills are prevalent. These social conditions are vital for the production of rubber and banana. For instance, the plantation of rubber trees, the harvest of latex, and the manufacturing of a transportable rubber product demands a considerable degree of technological knowledge [73,74]. In comparison to cassava and upland rice, the knowledge base among farmers regarding new commercial crops is still limited [72].

\subsection{Future Perspective on Agriculture in A Luoi district}

Significant changes in investment, household income, and policies have occurred in the Vietnamese agricultural sector within the last decades [75-77]. Traditional agricultural practices are gradually replaced by rather market-oriented food and commodity production [68]. However, agricultural production in Vietnam still faces many serious challenges, such as marker price volatility, financial resources, and farming skills [78]. These difficulties are more serious in the upland regions, where ethnic people groups occupy the majority of population [62].

In the following, the land evaluation results will be discussed in respect to the 2030 land use development plan for A Luoi district [79]. Crop diversification is found to stabilize incomes and enhance resilience [80]. A mixed agricultural land use planning involving commercial and non-commercial crops is a promising land use scheme for A Luoi district. Rubber, banana, and rice should exclusively be cultivated in the flat land, while acacia and cassava should expand in the rural area and remote communes.

According to the land use planning of A Luoi district, rice expansion is planned on 2300 to 2500 hectares in all communes, specifically in Huong Phong, Hong Ha, and Huong Nguyen. Nonetheless, rice cultivation will not be possible in these areas without the implementation of appropriate coping strategies that are aimed at an enhanced level of soil nitrogen and carbon. An expansion of rice fields towards Hong Bac and Hong Trung, represents an optional strategy.

Acacia is an exceptional commercial land use type, for which the expanded area of cultivation is encouraged and social acceptance is high. The expansion will especially be carried out on bared lands, which is in line with the outcomes of the land suitability evaluation. However, the intended 
conversion of current coffee zones to acacia plantations might be challenging, as this region is not suitable for any of the evaluated land use types.

Cassava, similarly to acacia, can flexibly be planted within many communes, even in remote areas. Intercropping could be applied for this kind of land use as well as acacia to supply the many food factories in Hue and Da Nang city. It also helps local farmers increase income and saving investments through the reduction of fertilizers.

Regarding banana, the district has a plan to expand up to 200 to 250 hectares in some communes in the northern part of the district and A Luoi Town. Potential banana planting in A Luoi commune is possible based on the performed land suitability evaluation. Communes that are designated for banana production in the future land use plan are less suitable when compared to the central valley communes of A Ngo, Son Thuy, and Phu Vinh.

Concerning rubber production, the future-zoning plan for A Luoi district intends to expand the rubber plantations on 1000 to 1500 hectares in Phu Vinh and Son Thuy communes and to maintain current rubber plantations. The findings of the land suitability evaluation suggest rubber expansion within Son Thuy commune, even though this area seems more suitable for acacia. Phu Vinh commune had been evaluated as being unsuitable for rubber production, which is not the case when considering the performed suitability evaluation. The current rubber plantation zones (in Hong $\mathrm{Ha}$, Nham commune) are unsuitable for rubber products according to the land suitability evaluation. This fact is in line with statements of locals during group discussions who mention that scattered rubber trees are only planted in these areas as a consequence of rubber subsidization programs, and are hence not sustainable on a long-term basis.

\section{Conclusions}

This research is the first GIS-based multi-criteria land suitability evaluation based on physical, economic, and social conditions, conducted in a hilly district of Central Vietnam. It provides a framework for land evaluation relevant to stakeholders in the district level of Vietnam. Moreover, land suitability evaluation can function as a vital planning tool to rationally assess sustainable agricultural practices for a region and enable the prevention of a trial and error process in agricultural land use planning. Therefore, land suitability evaluation should be a mandatory step before implementing any specific land use, especially in the agricultural sector.

In the frame of this research, it became apparent that future land use practices envisaged by planning authorities do not always coincide with the expectation of land user, scientists, and even different departments in the government system. The promotion of commercial crops, like rubber and banana in A Luoi district, needs careful consideration as major constraints, especially on the economic level prevail within the research area.

Author Contributions: Conceptualization, R.H., T.G.P. and M.K.; methodology, R.H., T.G.P. and D.W.; software, R.H. and T.G.P.; validation, R.H. and T.G.P.; formal analysis, R.H., T.G.P. and C.T.M.T.; investigation, T.G.P. and C.T.M.T.; resources, T.G.P. and C.T.M.T.; data curation, T.G.P. and C.T.M.T.; writing-original draft preparation, R.H., T.G.P. and D.W.; writing-review and editing, R.H., T.G.P., M.K. and D.W.; visualization, R.H and T.G.P.; supervision, M.K.

Funding: This research was funded by the Ministry of Education and Training of Vietnam via providing scholarship for the corresponding author to study Ph.D degrees at Göttingen University, grant number DA-911. The APC was funded by the Open Access Publication Fund of the University of Göttingen, Germany.

Acknowledgments: The authors thank the Vietnamese government for their financial support. This publication was supported financially by the Open Access Publication Fund of the University of Göttingen, Germany. We also thank the anonymous reviewers for their valuable comments, which greatly improved our paper.

Conflicts of Interest: The authors declare no conflict of interest. 


\section{References}

1. United Nations, Department of Economic and Social Affairs, Population Division. World Population Prospects: The 2017 Revision. Key Findings and Advance Tables; United Nations, Department of Economic and Social Affairs, Population Division: New York, NY, USA, 2017.

2. Food and Agriculture Organization of the United Nations. The State of the World's Land and Water Resources for Food and Agriculture. Managing Systems at Risk; Food and Agriculture Organization of the United Nations and Earthscan: Abingdon, UK, 2011; ISBN 978-1-84971-326-9.

3. United Nations, Department for Economic and Social. Sustainable Development Goals Report 2017; United Nations, Department for Economic and Social: New York, NY, USA, 2017; ISBN 978-92-1-101368-9.

4. Keesstra, S.; Mol, G.; de Leeuw, J.; Okx, J.; Molenaar, C.; de Cleen, M.; Visser, S. Soil-Related Sustainable Development Goals: Four Concepts to Make Land Degradation Neutrality and Restoration Work. Land 2018, 7, 133. [CrossRef]

5. Kapović Solomun, M.; Barger, N.; Cerda, A.; Keesstra, S.; Marković, M. Assessing land condition as a first step to achieving land degradation neutrality: A case study of the Republic of Srpska. Environ. Sci. Policy 2018, 90, 19-27. [CrossRef]

6. Ministry of Natural Resources and Environment of Vietnam. The Second Biennial Updated Report of Vietnam to the United Nations Framework Convention on Climate Change; Vietnam Publishing House of Natural Resources, Environment and Cartography: Ha Noi, Vietnam, 2017; ISBN 978-604-952-187-4.

7. Food and Agriculture Organization of the United Nations. World Food and Agriculture. Statistical Pocketbook 2018; FAO: Rome, Italy, 2018; ISBN 978-92-5-131012-0.

8. Quang, C.T.; Chung, T.K. Agricultural Land Policy in the Process of Agriculture E Rural Industrialization and Modernization in Vietnam. 2005. Available online: http://www.chinareform.org/publications/reports/200504/ t20050416_111326.htm (accessed on 15 December 2018).

9. de la Rosa, D.; van Diepen, C.A. Land Use, Land Cover and Soil Sciences. Qualitative and Quantitative Land Evaluations (Agro-Ecological Land Evaluation); Encyclopedia of Life Support Cultural Organization: Oxford, UK, 2002.

10. Verheye, W.H. Land Use, Land Cover and Soil Sciences. Land Evaluation; Eolss Publishers Co. Ltd.: Oxford, UK, 2009; ISBN 184826691X.

11. Ali Asghar, J.; Parisa, A.; Mohamed Reza, N.; Siamak, S. Land Suitability Evaluation of Bilverdy Research Station for Wheat, Barley, Alfalfa, Maize and Safflower. Soil Water Res. 2008, 3, 81-88.

12. Orhan, D.; Mustafa, U. Multi-criteria approach with linear combination technique and analytical hierarchy process in land evaluation studies. Eurasian J. Soil Sci. 2018, 7, 20-29.

13. Orhan, D.; Ceyhun, G.; Fatma Esra, S.; Semih, E. Parametric approach to land evaluation for forest plantation: A methodological study using GIS model. Afr. J. Agric. Res. 2010, 5, 1482-1496. [CrossRef]

14. van Huynh, C. Multi-Criteria Land Suitability Evaluation for Selected Fruit Crops in Hilly Region of Central Vietnam. With Case Studies in Thua Thien Hue Province; Shaker: Aachen, Germany, 2008; ISBN 3832268464.

15. Ayla, B.; Fadim, Y.; Asl1, D. AHP and GIS based land suitability analysis for Cihanbeyli (Turkey) County. Environ. Earth Sci. 2016, 75, 813-823. [CrossRef]

16. Alilou, H.; Rahmati, O.; Singh, V.P.; Choubin, B.; Pradhan, B.; Keesstra, S.; Ghiasi, S.S.; Sadeghi, S.H. Evaluation of watershed health using Fuzzy-ANP approach considering geo-environmental and topo-hydrological criteria. J. Environ. Manag. 2019, 232, 22-36. [CrossRef] [PubMed]

17. Nguyen, H.H. Evaluation of Coastal Sandy Land in Thanh Hoa province for Agricultural Development with Case study of Quang Xuong district. Ph.D. Thesis, Faculty of Mathematics and Natural Sciences, Greifswald, Germany, 2017.

18. Tran, D.T. Using GIS and AHP Technique for Land Use Suitability Analysis. In Proceedings of the International Symposium on Geoinformatics for Spatial Infrastructure Development in Earth and Allied Sciences, Ho Chi Minh City, Vietnam, 9-11 November 2006.

19. Liaghat, M.; Himan, S.; Bashir Rokni, D.; Farshid Sattari, A.; Seyed Navid, S.; Hadi, B. A Multi-Criteria Evaluation using the Analytic Hierarchy Process Technique to Analyze Coastal Tourism Sites. APCBEE Procedia 2013, 5, 479-785. [CrossRef]

20. Food and Agriculture Organization of the United Nations. Land Evaluation. Towards a Revised Framework; FAO: Rome, Italy, 2007. 
21. Food and Agriculture Organization of the United Nations. Agro-Ecological Zoning. Guidelines; FAO: Rome, Italy, 1996; ISBN 9251038902.

22. Sys, C.; Van Ranst, E.; Debaveye, J.; Beernaert, F. Land Evaluation. Part III Crop Requirements; Agricultural Publications: Brussels, Belgium, 1993.

23. Ahmed, S. Evaluation of the land resources for agricultural development. Case study: El-Hammam Canal and Its Extension, NW Coast of Egypt. Ph.D. Thesis, University of Hamburg, Hamburg, Germany, 2013.

24. Bagherzadeh, A.; Mansouri Daneshvar, M.R. Physical land suitability evaluation for specific cereal crops using GIS at Mashhad Plain, Northeast of Iran. Front. Agric. China 2011, 5, 504-513. [CrossRef]

25. Shahram, A. Land suitability evaluation for irrigated barley in Damghan plain, Iran. Indian J. Sci. Technol. 2011, 4, 1182-1187.

26. Abd El-Aziz, S.H. Evaluation of land suitability for main irrigated crops in the North-Western Region of Libya. Eurasian J. Soil Sci. 2018, 7, 73-86. [CrossRef]

27. Gaiser, T.; Graef, F. Optimisation of a parametric land evaluation method for cowpea and pearl millet production in semiarid regions. Agronomie 2001, 21, 705-712. [CrossRef]

28. Boje, G.; Rücker, G.; Senzige, S.; Skowronek, A. Skowronek. Land Suitability for Crop Diversification and Yield Potential of Drained Swamp Area in NW-Tanzania. Tropenlandwirt-J. Agric. Trop. Subtrop. 1998, 99 65-75.

29. Cools, N.; De Pauw, E.; Deckers, J. Towards an integration of conventional land evaluation methods and farmers' soil suitability assessment: A case study in northwestern Syria. Agric. Ecosyst. Environ. 2003, 95, 327-342. [CrossRef]

30. Zurayk, R.; el-Awar, F.; Hamadeh, S.; Talhouk, S.; Sayegh, C.; Chehab, A.-G.; Shab, K.A. Using indigenous knowledge in land use investigations: A participatory study in a semi-arid mountainous region of Lebanon. Agric. Ecosyst. Environ. 2001, 86, 247-262. [CrossRef]

31. Buthelezi, N.N.; Hughes, J.C.; Modi, A.T. The use of scientific and indigenous knowledge in agricultural land evaluation and soil fertility studies of two villages in KwaZulu-Natal, South Africa. Afr. J. Agric. Res. 2013, 8, 507-518. [CrossRef]

32. Davidson, D.A.; Theocharopoulos, S.P.; Bloksma, R.J. A land evaluation project in Greece using GIS and based on Boolean and fuzzy set methodologies. Int. J. Geogr. Inf. Syst. 1994, 8, 369-384. [CrossRef]

33. Shalaby, A.; AbdelRahman, M.A.E.; Belal, A.A. A GIS Based Model for Land Evaluation Mapping: A Case Study North Delta Egypt. Egyptian J. Soil Sci. 2017, 57, 339-351. [CrossRef]

34. Malczewski, J. GIS-based multicriteria decision analysis: A survey of the literature. Int. J. Geogr. Inf. Syst. 2006, 20, 703-726. [CrossRef]

35. Joerin, F.; Thériault, M.; Musy, A. Using GIS and outranking multicriteria analysis for land-use suitability assessment. Int. J. Geogr. Inf. Syst. 2001, 15, 153-174. [CrossRef]

36. Aldababseh, A.; Temimi, M.; Maghelal, P.; Branch, O.; Wulfmeyer, V. Multi-Criteria Evaluation of Irrigated Agriculture Suitability to Achieve Food Security in an Arid Environment. Sustainability 2018, 10, 803. [CrossRef]

37. People's Committee of A Luoi District. Statistical Year Book: 2005-2015; People's Committee of A Luoi District: Thua Thien Hue, Vietnam, 2015.

38. Food and Agriculture Organization of the United Nations. World Reference Base for Soil Resources 2014. International Soil Classification System for Naming Soils and Creating Legends for Soil Maps; FAO: Rome, Italy, 2014; ISBN 978-92-5-108369-7.

39. National Institute of Agricultural Planning and Projection of Vietnam. Soil Map of Thua Thien Hue Province (1/100000); National Institute of Agricultural Planning and Projection of Vietnam: Ha Noi, Vietnam, 2005.

40. Natural Resources and Environment Department of A Luoi District. Land Use Map of A Luoi District, Thua Thien Hue province, (1/50000); Natural Resources and Environment Department of A Luoi District: Thua Thien Hue, Vietnam, 2015.

41. Elsheikh, R.; Mohamed Shariff, A.R.B.; Amiri, F.; Ahmad, N.B.; Balasundram, S.K.; Soom, M.A.M. Agriculture Land Suitability Evaluator (ALSE): A decision and planning support tool for tropical and subtropical crops. Comput. Electron. Agric. 2013, 93, 98-110. [CrossRef]

42. Gia Pham, T.; Kappas, M.; van Huynh, C.; Hoang Khanh Nguyen, L. Application of Ordinary Kriging and Regression Kriging Method for Soil Properties Mapping in Hilly Region of Central Vietnam. ISPRS Int. J. Geo-Inf. 2019, 8, 147. [CrossRef] 
43. United States Geological Survey (USGS). Digital Elevation-Shuttle Radar Topography Mission (SRTM) 1 Arc-Second Global; Raster; 2000. Available online: https://earthexplorer.usgs.gov/ (accessed on 1 June 2018).

44. Thua Thien Hue Meteorological Station. Hydrometeorolical Annual Reports from 2005 to 2017; Thua Thien Hue Publishing House: Hue city, Vietnam, 2017.

45. Paul, R. Participatory Rural Appraisal (PRA) Manual; FAO: Castries, Saint Lucia, 2013.

46. Saaty, R.W. The analytic hierarchy process-What it is and how it is used. Math. Model. 1987, 9, $161-176$. [CrossRef]

47. Ahmed, G.B.; Shariff, A.R.M.; Balasundram, S.K.; Fikri bin Abdullah, A. Agriculture land suitability analysis evaluation based multi criteria and GIS approach. IOP Conf. Ser. Earth Environ. Sci. 2016, 37, 12044. [CrossRef]

48. Akınc1, H.; Özalp, A.Y.; Turgut, B. Agricultural land use suitability analysis using GIS and AHP technique. Comput. Electron. Agric. 2013, 97, 71-82. [CrossRef]

49. Das, P.T.; Sudhakar, S. Land Suitability Analysis for Orange \& Pineapple: A Multi Criteria Decision Making Approach Using Geo Spatial Technology. J. Geogr. Inf. Syst. 2014, 06, 40-44. [CrossRef]

50. Wang, Z.; Deng, X.; Song, W.; Li, Z.; Chen, J. What is the main cause of grassland degradation? A case study of grassland ecosystem service in the middle-south Inner Mongolia. CATENA 2017, 150, 100-107. [CrossRef]

51. Saaty, T.L. Decision making with the analytic hierarchy process. Int. J. Serv. Sci. 2008, 1, 83-98. [CrossRef]

52. Nguyen, T.T.; Verdoodt, A.; Van, T.Y.; Delbecque, N.; Tran, T.C.; van Ranst, E. Design of a GIS and multi-criteria based land evaluation procedure for sustainable land-use planning at the regional level. Agric. Ecosyst. Environ. 2015, 200, 1-11. [CrossRef]

53. Food and Agriculture Organization of the United Nations. A Framework for Land Evaluation; Food and Agriculture Organization of the United Nations: Rome, Italy, 1976; ISBN 92-5-100111-1.

54. AbdelRahman, M.A.E.; Natarajan, A.; Hegde, R. Assessment of land suitability and capability by integrating remote sensing and GIS for agriculture in Chamarajanagar district, Karnataka, India. Egypt. J. Remote Sens. Space Sci. 2016, 19, 125-141. [CrossRef]

55. El Baroudy, A.A. Mapping and evaluating land suitability using a GIS-based model. CATENA 2016, 140, 96-104. [CrossRef]

56. Dan, N.N.; Ping, L.G.; Le Lang, P.C. Land Unit Mapping and Evaluation of Land Suitability for Agro-forestrye in Thua Thien Hue province-VietNam as an Example. IOP Conf. Ser. Earth Environ. Sci. 2018, 159, 12012. [CrossRef]

57. Zolekar, R.B.; Bhagat, V.S. Multi-criteria land suitability analysis for agriculture in hilly zone: Remote sensing and GIS approach. Comput. Electron. Agric. 2015, 118, 300-321. [CrossRef]

58. Mu, E.; Pereyra-Rojas, M. Practical Decision Making Using Super Decisions V3. An Introduction to the Analytic Hierarchy Process; Springer: Cham, Germany, 2017; ISBN 9783319683683.

59. Ossadnik, W.; Schinke, S.; Kaspar, R.H. Group Aggregation Techniques for Analytic Hierarchy Process and Analytic Network Process: A Comparative Analysis. Group Dec. Negot. 2016, 25, 421-457. [CrossRef]

60. Saaty, T.L.; Peniwati, K. Group Decision Making. Drawing out and Reconciling Differences, Revised edition; RWS Publications: Pittsburgh, PA, USA, 2012; ISBN 1888603089.

61. Lee, J.; Gereffi, G.; Beauvais, J. Global value chains and agrifood standards: challenges and possibilities for smallholders in developing countries. Proc. Natl. Acad. Sci. USA 2012, 109, 12326-12331. [CrossRef] [PubMed]

62. Yen, B.T.; Visser, S.M.; Hoanh, C.T.; Stroosnijder, L. Constraints on Agricultural Production in the Northern Uplands of Vietnam. Mt. Res. Dev. 2013, 33, 404-415. [CrossRef]

63. Pereira, J.M.C.; Duckstein, L. A multiple criteria decision-making approach to GIS-based land suitability evaluation. Int. J. Geogr. Inf. Syst. 1993, 7, 407-424. [CrossRef]

64. Nisar Ahamed, T.R.; Gopal Rao, K.; Murthy, J.S.R. GIS-based fuzzy membership model for crop-land suitability analysis. Agric. Syst. 2000, 63, 75-95. [CrossRef]

65. Zadeh, L.A. Similarity relations and fuzzy orderings. Inf. Sci. 1971, 3, 177-200. [CrossRef]

66. Joss, B.N.; Hall, R.J.; Sidders, D.M.; Keddy, T.J. Fuzzy-logic modeling of land suitability for hybrid poplar across the Prairie Provinces of Canada. Environ. Monit. Assess. 2008, 141, 79-96. [CrossRef]

67. Malczewski, J. GIS-based land-use suitability analysis: A critical overview. Prog. Plan. 2004, 62, 3-65. [CrossRef] 
68. Clemens, G.; Fiedler, S.; Cong, N.D.; van Dung, N.; Schuler, U.; Stahr, K. Soil fertility affected by land use history, relief position, and parent material under a tropical climate in NW-Vietnam. CATENA 2010, 81, 87-96. [CrossRef]

69. Thomas, H.; Alwin, K.; Melvin, L.; Mattiga, P.; Camille, S.-M.; Manfred, Z.; Wanwisa, P.; Tuan, V.D.; Georg, C. Soil Conservation on Sloping Land: Technical Options and Adoption Constraints. In Sustainable Land Use and Rural Development in Southeast Asia: Innovations and Policies for Mountainous Areas; Fröhlich, H.L., Schreinemachers, P., Stahr, K., Clemens, G., Eds.; Springer: Berlin/Heidelberg, Germany, 2013; pp. 229-279. ISBN 978-3-642-33376-7.

70. Zeller, M.; Ufer, S.; Van, D.T.T.; Nielsen, T.; Schreinemachers, P.; Tipraqsa, P.; Berger, T.; Saint-Macary, C.; Van, L.T.A.; Keil, A.; et al. Policies for Sustainable Development: The Commercialization of Smallholder Agriculture. In Sustainable Land Use and Rural Development in Southeast Asia: Innovations and Policies for Mountainous Areas; Springer: Berlin/Heidelberg, Germany; pp. 463-490.

71. Maraseni, T.N.; Son, H.L.; Cockfield, G.; Duy, H.V.; Nghia, T.D. Comparing the financial returns from acacia plantations with different plantation densities and rotation ages in Vietnam. For. Policy Econ. 2017, 83, 80-87. [CrossRef]

72. Fox, J.; Castella, J.-C.; Ziegler, A.D.; Westley, S.B. Rubber Plantations Expand in Mountainous Southeast Asia: What Are the Consequences for the Environment? 2014. Available online: https://www.eastwestcenter.org/ system/tdf/private/api114.pdf?file=1\&type=node\&id=34563 (accessed on 15 September 2018).

73. To, X.P.; Tran, H.N. Rubber Expansion and Forest Protection in Vietnam; Tropenbos International Viet Nam: Hue, Vietnam, 2014.

74. Nguyen, T.T.H. Solutions to improve the value added of the rubber value chain in the Central Highlands of Vietnam. Australasian Agribus. Persp. 2018, 21, 89-97.

75. Van de Fliert, E.; Pham, T.V.; Do, T.M.H.; Thomas, P.; Nicetic, O. Out of comfort zones, into realities: research for development with upland ethnic minority communities in North West Vietnam. In Building Sustainable Rural Futures, The added Value of Systems Approaches in Times of Change and Uncertainty, Proceedings of the 9th European IFSA Symposium, Vienna, Austria, 4-7 July 2010; Darnhofer, I., Michaela, G., Eds.; BOKU: Wien, Austria, 2010; pp. 330-342, ISBN 978-3-200-01908-9.

76. World Bank. Vietnam Development Report 2016. Transforming Vietnamese Agriculture: Gaining More from Less; Hong Duc Publishing House: Ha Noi, Vietnam, 2016; ISBN 978-604-948-014-0.

77. Alwin, K.; Camille, S.-M.; Manfred, Z. Intensive Commercial Agriculture in Fragile Uplands of Vietnam: How to Harness its Poverty Reduction Potential while Ensuring Environmental Sustainability? Q. J. Int. Agric. 2013, 52, 1-25.

78. Tran, T.H.M.; Nguyen, T.H.Y. Vietnam's Agriculture towards Sustainable Development: Opportunities, Challenges and Solutions in the context of International Economic Integration nowadays. South East Asia J. Contemp. Bus. Econ. Law 2018, 15, 63-70.

79. People's Committee of A Luoi District. The draft land use plan of the A Luoi district in 2030. 2018; Unpublished work.

80. Nguyen, H.Q. Analyzing the economies of crop diversification in rural Vietnam using an input distance function. Agric. Syst. 2017, 153, 148-156. [CrossRef]

(C) 2019 by the authors. Licensee MDPI, Basel, Switzerland. This article is an open access article distributed under the terms and conditions of the Creative Commons Attribution (CC BY) license (http://creativecommons.org/licenses/by/4.0/). 